\title{
Embedded Urbanism: Shakespeare in the City
}

\section{Roy Eriksen}

\section{(2) OpenEdition}

\section{Journals}

Electronic version

URL: http://journals.openedition.org/shakespeare/1610

DOI: 10.4000/shakespeare.1610

ISSN: 2271-6424

\section{Publisher}

Société Française Shakespeare

\section{Printed version}

Date of publication: 1 March 2011

Number of pages: $67-80$

ISBN: 2-9521475-7-4

\section{Electronic reference}

Roy Eriksen, «Embedded Urbanism: Shakespeare in the City », Actes des congrès de la Société française Shakespeare [Online], 28 | 2011, Online since 15 February 2011, connection on 10 December 2020. URL : http://journals.openedition.org/shakespeare/1610; DOI : https://doi.org/10.4000/shakespeare. 1610 


\section{Shakespeare et la Cité}

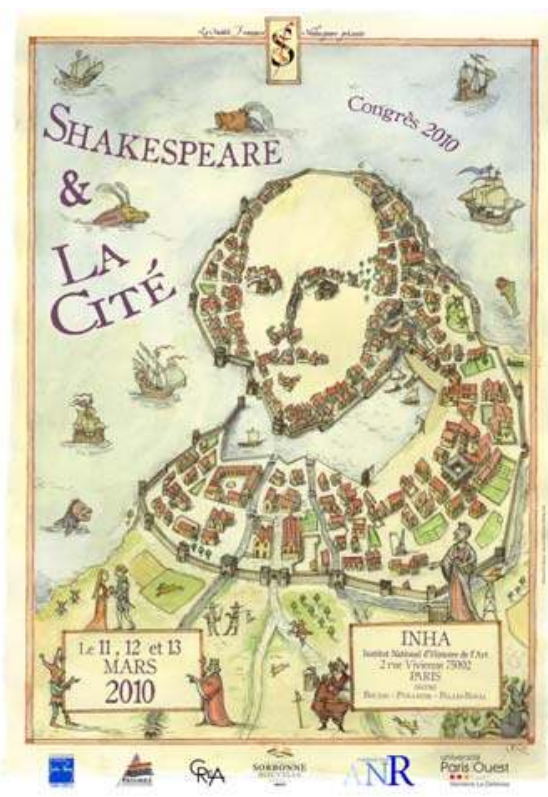

actes du Congrès

organisé par la

SOCIÉTÉ FRANÇAISE SHAKESPEARE

les 11,12 et 13 mars 10

textes réunis par

Pierre KAPITANIAK

sous la direction de

Dominique GoY-BLANQUET 
COUVERTURE :

Edouard Lekston 2010

conception graphique et logo

Pierre Kapitaniak

\section{(C) 2011 Société Française Shakespeare Institut du Monde Anglophone} Université de Paris III - Sorbonne Nouvelle 5 rue de l'École de Médecine 75006 Paris

www.societefrancaiseshakespeare.org réservés pour tous les pays 


\title{
EMbedded URbanism: SHAKeSPEARE IN THE City
}

\author{
Roy ERIKSEN
}

\begin{abstract}
Que pensait Shakespeare de la ville? Dans Tamburlaine, Marlowe s'attache aux structures poétiques modelées sur l'architecture du monde, utilisant la toute nouvelle carte d'Ortelius lorsqu'il décrit les détails géographiques du monde réel. Dans Doctor Faustus (B) il dessine avec expertise la topographie d'une Rome lumineuse et splendide, détaillant ses principales caractéristiques à l'aide du vocabulaire architectural en vogue (site, situation, plan, ériger). A l'instar de son contemporain, Shakespeare a lui aussi recours de temps en temps aux termes architecturaux comme des références en soi, mais semble s'intéresser assez peu à la ville réelle ou aux villes crées dans ses pièces. Pour le gentilhomme du Warwickshire, la ville -souvent italienne apparaît souvent soit comme un dédale déroutant, soit comme un lieu de contrôle, de provocation ou de violence de rue, un cadre qui contraste avec le monde villageois transparent et réceptif de The Merry Wives. Cet article propose de démêler et d'analyser brièvement la mise en abyme de la ville dans les pièces urbain de The Two Gentlemen of Verona et Romeo and Juliet à Comedy of Errors et Coriolanus, afin d'expliquer l'apparent scepticisme de Shakespeare à l'égard de l'expérience urbaine.
\end{abstract}

What was Shakespeare's take on the city? Marlowe in Tamburlaine was concerned with poetic structures modelled on the architecture of the world and using Ortelius's state of the art-map when describing in detail the geography of the actual world. In Doctor Faustus $(B)$ he expertly draws the topography of bright splendent Rome, detailing its main features with current architectural terms (site, situation, ground-work, underprop, erect). Like his exact contemporary before him, Shakespeare, too, on occasion uses architectural terms almost as self-referring passages, but seems to take little interest in the actual city or cities emplotted in his plays. For the Warwickshire gentleman Shakespeare, the city - often an Italian one - frequently appears either to be maze-like and confusing, or a place of control, entrapment and street violence, a setting that contrasts with the transparent and receptive village world in e.g. The Merry Wives. This article teases out and analyzes briefly the embeddedness of the city in some urban plays from The Two Gentlemen of Verona and Romeo and Juliet to Comedy of Errors and Coriolanus with a view to explaining Shakespeare's apparent skepticism to the urban experience.

$\mathrm{W}$

hat was Shakespeare's take on the city? This article focuses on how the dramatist represents the city, or more particularly on how some of his more urban plays are "embedded" in the surrounding city and relate to contemporary attitudes to the city. Shakespeare's plays like other texts belong in socio-economic and cultural spaces that follow laws of causality and logic of their own. They are in a striking metaphor embedded in larger and different contexts and texts, operating in arenas that are continually subjected to change in the form of colonization and invasion. A city is such a vast and comprehensive text that is in continual flux, a site in which the theatre and stage plays are embedded in on-going complex processes. "Embeddedness" is a central concept within economic and institutional sociology, being launched by the Hungarian economist Karl Polyani, in the seminal study The Great Transformation (1944), who opposed the idea in economic theory that 
the market exists independently from society and possesses its own inherent logic and dynamics. ${ }^{1}$ In the manner that literary works used to be studied in well-nigh total isolation from their social and ideological contexts, architecture and urbanism too have been studied within similar formalistic frames of analysis, as a pure tekne superimposed upon sites and cities and following abstract laws of their own, ${ }^{2}$ an analytical approach that today is outmoded.

We do not know much about what Shakespeare's thoughts about actual cities or urbanism were, but he has been studied in relation to idea of the city. ${ }^{3}$ Judging by his work and recorded life, we know that he took an interest in architecture. Just how his own house, New Place at Stratford-upon-Avon, may have been shaped by that interest, the on-going explorative excavations on the site of the no longer extant building will possibly tell us. Shakespeare was certainly more akin to Prospero in The Tempest, than to men like Lord Burghley who imported "pattern books" from Italy, and built stately Italianinspired country houses. ${ }^{4}$ Interestingly, when the banished wizardduke of Milan, explains to Ferdinand the nature of his faded "insubstantial pageant" (IV.i.155), he refers to and rejects the type of idealised townscape or architectural vision we most readily, but imprecisely, associate with Renaissance urbanism:

These our actors,

As I foretold you, were all spirits, and

Are melted into air, into thin air;

And, like the baseless fabric of this vision,

The cloud-capped towers, the gorgeous palaces,

The solemn temples, the great globe itself,

Will dissolve...

(IV.i.148-154)

By means of his mouthpiece Shakespeare here implicitly discloses a critical attitude to the new and outlandish type of preconceived model

\footnotetext{
${ }^{1}$ Kenneth McRobbie (ed.), Humanity, Society and Commitment: On Karl Polanyi, Toronto: Black Rose Books Ltd., 1994.

${ }^{2}$ A recent example of this attitude is Liutpold Frommel who discusses abstract forms and their relationship live a life of their own, being almost untouched by the contingencies of the world and materiality. The Architecture of the Italian Renaissance. London: Thames and Hudson, 2008.

${ }^{3}$ Gail Paster, The Idea of the City in the Age of Shakespeare, Athens: The University of Georgia Press, 1985 and Jean Remple, The Myth of Venice in the Elizabethan Mind, Tromsoe: Nordlit, 1995.

4 Mark Girouard, Elizabethan Architecture. London: Thames and Hudson, 2009, 53; 176.
} 
city, seen for example in Antonio Filarete's complimentary and unrealised ville radieuse outlined in his Trattato della Architettura. ${ }^{5}$

Shakespeare's visionary cityscape is nevertheless Early Modern, whereas the imagined cities, small and great, in Thomas More's in Utopia cannot be said to be expressive of any kind of Early Modern urbanism, - neither in relation to the common notion of the ideal city or its socio-political implications; it is firmly medieval. What we associate most readily with a Renaissance ideal city are perspective representations like the so-called Urbino or Baltimore panels, which are exercises in perspective construction or templates made for painters. We know that the theoretician of linear perspective, Leon Battista Alberti, made such no longer extant perspectives, but we spy similar ones in contemporary and later paintings by Ghirlandaio, Piero della Francesca, and Perugino. Besides these spookily empty orthogonal constructions are not symmetrical in the popular sense of "dead" symmetry, but display a variety of building types and styles, ranging from all'antica building, late Gothic and early Renaissance. ${ }^{6}$ They are thus perspective anticipations of the material cityscape we can experience at Pienza in Tuscany, in Bernardo Rosselino's realization of Alberti's scheme for the transformation of the village Corbignano, the birthplace of Pope Pius II.7 The medieval or early Renaissance social hierarchy embedded in the city as built, again reminds us of the widespread and imprecise opinion that a Renaissance town need have an ideal design. Contrary to opinion I would argue that there are two main kinds of Renaissance city or two types of urbanism: an aristocratic or absolutist urbanism represented by Sforzinda, Palma nova and Sabbioneta; and a republican one, based in particular on the stylistic ideal of convenientia with varietas and a dialogic principle, dialogue being the preferred genre of Humanists like Alberti. Pienza is possibly the best extant example but the plan for the Borgo in Rome, surviving only in the prose of Antonio Manetti's Vita ac gestis (1453), embodies similar principles. ${ }^{8}$

5 Antonio Averlino, il Filarete, Trattato di architettura (1462-66), 2 vols, ed. A.M. Finoli and L. Grassi, Milan: Il Polifilo, 1972.

6 The pictured buildings vary both in type, style, size and alignment, Serlio's "Scena Tragica" and "Scena Comica" being good late $16^{\text {th }}$ century examples.

${ }^{7}$ For Pienza, see Christine Smith, Architecture in the Culture of Early Humanism: Ethics, Aesthetics, and Eloquence 1400-1470. New York and London: O.U.P., 1992.

8 Iannotii Manetti, De vita ac gestis Nicolai quinti summi pontificis, edited and translated by Anna Modigliani, Roma: Istituto Storico Italiano per il Medio Evo, 2005, for a 
Prospero's speech quoted above reveals an interest in ethical architectonics and the difference between appearance and essence, rather than in utilising such cityscapes as positive examples of human ingenuity. In this emphasis he differs from Marlowe who in his plays is concerned with a rhetorical or poetic structure that is closely modelled on "the architecture of the world" and that reflects actual geography. In Tamburlaine he uses Abraham Ortelius's state of the art world atlas, Theatrum Orbis Terrarum (Antwerp, 1570) and in Doctor Faustus he expertly reproduces the topography of "bright splendent Rome" (B 852), detailing the city's main natural features while using architectural terms (site, situation, ground-work, underprop, and erect). In a remarkably accurate speech in the first scene at the papal court, he even appears to let the actual structure of the urbs aeterna be reflected in the symmetrical outline of Mephostophilis's survey of Rome:

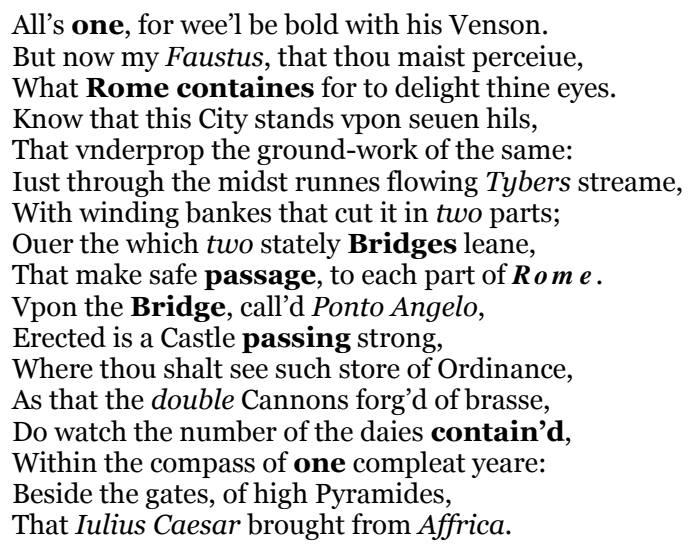

In the 17-line speech describing how the Tiber cuts Rome into two parts, there is a cluster of words underpinning that fact ("iust through the midst", "two parts", "two Bridges", "double Cannons"), so that the actual divided topography of the urbs becomes a template for the speech itself and its distribution of semiotic markers (one/Rome containes/Bridges/passage//Rome//Bridge/passing/contain'd/one). It

topomorphical analysis of the plan, see my “Alberti, Manetti, and Quattrocento Aesthetics," in eds. Roy Eriksen and Victor Plahte Tschudi, Ashes to Ashes. Art in Rome between Humanism and Maniera, Pisa / Roma: Edizioni dell'Ateneo, 2006, pp. 49-70. 
is repetitional pattern typical of the Marlovian speech and its corresponding in the A-text typically fails to reproduce its pattern. For the recommendation of such patterning cum accompanying textual analysis by Tarquato Tasso, see the latter's Lezione on a sonnet by Giovanni della Casa. ${ }^{9}$

Like Marlowe before him Shakespeare sometimes uses architectural terms almost as self-referring passages and comments on the action. In fact, sporting current architectural terminology seems to have been fashionable among Elizabethan writers in general, if we consider writers as different as Richard Wills, George Gascoigne, George Puttenham, Samuel Daniel, and William Scott. ${ }^{10}$ In 2 Henry IV (I.iii.35-62) Shakespeare reveals a surprising number of both traditional native and up-to-date Italian terms in relation to building and to the planning of a work in hand (plot of situation, model, foundation, and erection). For instance, the English term "plot" corresponding to "site," or a place ready to receive the "ground-work" acquires the sense of a dramatic action. ${ }^{11}$ In the speech from 2 Henry IV Lord Bardolph considers a line of action that will coincide with the ensuing action, and does so using architectural terms. That coincidence may of course be given structural expression in terms of the actual dispostio and elocutio, but tells us little about how such metaphors bear on the city embedded in the play.

For Shakespeare the city - often an Italian one - frequently appears either to be maze-like and confusing, a place for entrapment and violence, wholly unlike the symmetrical designs made for Renaissance absolutist rulers (and alluded to by Prospero), a place where order is imposed, and not organic. The harsh laws operative in cities point to Shakespeare's negative attitude to city life and its strictures. Such a labyrinthine city world exists in contrast to the transparent and receptive village world encountered in The Merry Wives of Windsor, where action is set at a few traditional, if not archetypal locations: the cottage, the tavern, the commons and the forest.

\footnotetext{
${ }^{9}$ See my discussion in The Building in the text. Alberti to Shakespeare and Milton, University Park, Pennsylvania: University of Pennsylvania Press, 2001, pp. 112-17.

${ }^{10}$ See my "Shaping the Sonnet Italian Style: Petrarch, Tasso, Daniel and Shakespeare", in ed. Sonja Fielitz, Shakespeare's Sonnets: Loves, Layers, Languages, Heidelberg: Universitaetsverlag C. Winter, 2010 (forthcoming).

${ }^{11}$ The Building in the text, pp. 1-10.
} 
In spite of spending most of twenty-five years in London, Shakespeare never became a Londoner. As Park Honan reminds us, "he was born, married and buried in Stratford-upon-Avon. And this provincial town remained, in most senses, his home." ${ }^{12}$ And I would strongly argue that his mind-set remained very much of the village, when in play after play he tries to give ethical order and dimension to human life. This contrasts with the urban mind-set of Leon Battista Alberti, for whom the city was the highest achievement of public architecture, citizens and buildings alike being the ornaments of the city state.

Shakespeare in his approach drew on architecture in the spirit of Luke 14.28-30, that is, in terms of edification, focusing on the ideological and human, rather than on the physical, particular and material aspects of the city that Stowe, Dekker, and Lodge anatomized in their pamphlets and plays. In the metaphor of Stowe, London as a subject became "a Citizen" and an all pervasive "character" in itself, and these authors' various descriptions of the metropolis together constitute a "mode" embedded in their plays. Shakespeare does not engage directly with the city or London to any great extent, and even when compared to Marlowe his preferences and perhaps sympathies as regards the urban scene are different.

In the same way that we may speak of Shakespeare as a grammar school wit, being different from the University Wits or the urban born practical men of the stage, we may usefully distinguish between two kinds of urban plays in his dramatic oeuvre. For instance, his three socalled city comedies, if we may call them that, differ greatly in mood and characters from the urban comedies (or other urban plays) of his contemporaries regardless whether they are university or theatre trained. In fact, the Shakespearean urban play in its purest form is The Merry Wives of Windsor, a play entirely set in the natural "comic" habitat of the village. For here Shakespeare focuses on the oikos rather than the polis, and this preference emerges not only in the comedies, but in many tragedies and the histories, as well. In The Merry Wives of Windsor we encounter the whole range of characters belonging to the village or small market town, Falstaff being the urban Other, who in

12 Park Honan, The Lodger. Shakespeare on Silver Street, London: Allen Lane, 2007, p. 32. 
the end is transformed and reformed by his meeting with the goodnatured characters of the life-world of the village, which nostalgically represent the unfallen village or pastoral world. In contrast, in 2 Henry IV Falstaff is evicted from the polis, being a representative of the predatory forces that from within threaten the order of that larger oikos, and the dominant code of utility that determines the ideology and the sharing of power of the Tudor regime.

What is missing in Henry $I V$ is the embeddedness of the material city, the new Early Modern city, in the dramatic world, or vice versa the signs or semiotic resources that reveal how the plays are inscribed in the urban matrix they represent and are set in. For all their grotesque metaphors the main dramatic loci are still those of the tavern and the court - the city between these emblematic locations has melted or collapsed. Although Henry IV is not a city comedy, but contains a persistent strand of comic action we associate with the darker side of urban life, we see in the two plays what Gail Paster in The Idea of the City in the Age of Shakespeare noted as Shakespeare's tendency to "ruralize":

Shakespeare tends to ruralize his city comedies: The Messina of Much Ado, the Padua of Taming of the Shrew and the Athens of Midsummer Night's Dream lack almost all the nitty-gritty traces of urban habitation but the name. ${ }^{13}$

The grotesqueness of Falstaff matches that of Thomas Nashe's Jack Wilton and some of the novella's cronies, but he does not at all move in the same urban landscape. Wilton moves in cityscapes whereas Falstaff moves between taverns, an opening in the forest, and along country roads. In fact, there is little in the plays mentioned by Paster that turns them into city plays to the exclusion of others like Twelfth Night; or distinguishes them from the three plays she presents as "Shakespeare's City Comedies": The Comedy of Errors, The Merchant of Venice, and Measure for Measure. ${ }^{14}$

Romeo and Juliet is a case in point: being set in Verona the love tragedy at first promises to be an Italianate urban comedy about obstacled but eventually conquering young love, displaying all the characteristics of the comic formula while courting the conventions of

\footnotetext{
13 Op. cit., p. 178
}

14 Ibid. 
Italian tragicomedy in its use of threatened violence from the very beginning. Although opening with a street scene and a market place brawl which is stopped by Prince Escalus, the first scene is a play in itself, being ideologically and compositionally controlled from above, but there is no firm sense of an urban space, no obvious use of comic mansiones around a piazza. Soon orchards, individual houses with walls, gardens, and fields take over, that is, the open structures of the village, not the narrow streets of the Renaissance city. Romeo wanders under sycamore trees, Friar Laurence picks herbs in a field, Romeo hides in an orchard, the Nurse is accosted in a piazza on the way to church, etc. In the play open spaces vie with interiors.

When this is said there are many instances in Shakespeare's dramatic verse that communicate and underline the fundamental role of architecture in Early Modern thought and writing. The best example is Lord Bardolph's speech in 2 Henry IV, yet there is no equivalent interest in urbanism or "ideal cities." However, the symbolism audible in Bardolph's words occurs for instance when in the early play, The Comedy of Errors, Luciana asks,

Shall, Antipholus,

Even in the spring of thy love thy love-springs rot? Shall love in building grow so ruinous?

(III.ii.2-4)

Similarly, in The Two Gentlemen of Verona, Valentine begs for Silvia's favours within the platonic architectural metaphor of the body as artefact:

$\mathrm{O}$ thou that dost inhabit in my breast,

Leave not the mansion so long tenantless

Lest, growing ruinous, the building fall

And leave no memory of what it was.

Repair me with thy presence, Sylvia.

(v.iv.9-11)

We are reminded of the negative image of the house without a roof, but the metaphor does not approach Plato's of the body as a city, which Shakespeare reserves for the patrician Menenius's parable in Coriolanus of the mutinous body drawn from Aesop. The patrician tells a tale that is essentially political and ideological, and it does not reflect on how Shakespeare in the play reduces Rome to an idea and a site for ideological conflict, rather than to a diversified oikos of conflicting interests based on concrete and material economic concerns. In the 
earlier Roman play, Titus Andronicus, Aaron, who works from a Machiavellian hidden design on his opponents' lives, is dubbed by his victims "architect and plotter of these woes," thus being a poet of actions (v.iii.121). ${ }^{15}$ Whereas Muriel Cunin observes that "[p]our Shakespeare, nous le verrons, l'édification semble passer davantage par l'architecture poétique que par l'architecture imaginaire,"16 I would like to add that there is a decided movement towards ethics and away from the actual urban setting of the dramatic action as well as of the playhouse itself. In this sliding away from or avoidance of city contingencies Shakespeare differs from many of his contemporaries in his emphases.

The strong impulse to politicize comedy, that is, its purpose to condemn vices by presenting biting satires of human weakness, is developed in the direction of political and cultural critique by Marlowe in his innovative The Jew of Malta. The play which represents the first dramatic instance of sustained black comedy and satire, springs from the matrix of Italianate city comedy, ${ }^{17}$ and is a play that is deeply embedded in Elizabethan mercantile culture and politico-religious conflicts. The population of a merchant city is reflected in its sheer range of characters; people of different nationalities and creeds (Italians, Spanish, Turks, and Jews; Catholics, Moslems, and Judaists); and, most importantly, members of many social groups and trades (aristocrats, burghers, knights, soldiers, friars, nuns, servants, workers, slaves, prostitutes, and pimps). In other words, Marlowe's Malta is a community not dissimilar in structure to that of European city states or merchant republics, that had grown in population, complexity, economic diversity, and wealth due to the inclusion of persons originally foreign to the locality. Such a range of characters is rare in

15 On Shakespeare's use of plot in relation to Alberti and early Elizabethan practice by e.g. Shute, Gascoigne and Dee, see my "The Lineaments of Influence: Alberti and the Elizabethans," eds. Gunnar Sorelius and Michael Srigley, Cultural Exchange between European Nations in the Renaissance, Uppsala, 1994, pp. 69-84, and, more recently, Girouard, Elizabethan Architecture, pp. 58-59.

${ }^{16}$ Muriel Cunin, Shakespeare et l'architecture. Nouvelles inventions pour bien bâtir et bien jouer, Paris: Honoré Champion, 2008, p. 282.

${ }^{17}$ I believe that he had experimented with this form of Italianate comedy in the unconventional and "anonymous" play The Taming of a Shrew, which I attribute to Marlowe in view of its prominent use of the dramatist's preferred devices in speech and plot construction-in addition to being full of echoes from Tamburlaine and Faustus. "The Taming of A Shrew: Composition as Induction to Authorship," NJES Vol. 4, No. 2 (December 2005), pp. 41-61; rtd. in ed. Erreur ! Référence de lien hypertexte non valide. 
Shakespeare who seems to have been less engaged by or involved with the city as a market in his art, although he had entrepreneurial skills, invested in property, and lived with economically successful Huguenots. To my mind the main exception in the oeuvre is The Merchant of Venice, in which the Law rather than the Market propels the conflict and there is no prominent use of the green world, the Shakespearean antidote to the city.

For the very existence in particular in Shakespeare, Lyly and Elizabethan comedy of a green world of transformation, revival and freedom, if only momentarily, inherently communicates the idea of the city as something Italian and negative. If unchecked, city life constitutes the oppressive opposite that prevents the establishment of a desired inclusive comic society with which to end a play. A place of injustice due to harsh and inhumane laws embodied in and executed by rigid representatives of patriarchy, or an arena of social unrest in response to oppression is what the city becomes. Frequently the people, the mob or simply citizens armed with clubs and pikes are ridiculed or scoffed at when claiming to be the city. In the fable told by Menenius in Coriolanus, all the social groups of Republican Rome are included, but his model is a hierarchical one, with his own class, the patricians, on top. The smugness and patronizing attitude of Menenius underscore this fact, comparing the city to a body, speaking in the voice of the belly in the defence of order and hierarchy:

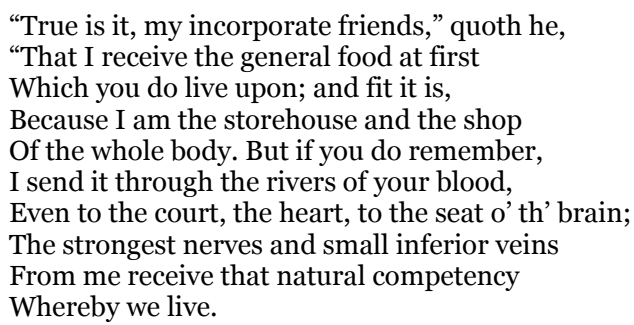

Menenius reads the rebellious plebeians a lecture in political philosophy and ethics, in favour of status quo, and Shakespeare lets him do it in relation to a city (the storehouse, the shop, the court), but one controlled from the top.

Thus in Coriolanus the city has become civitas, the larger oikos, and the citizens' ethos has become ideology; "the city on the move and 
the make" - to cite Michael Coveney - has dissolved and received a fixed form of governance. For together with the paucity of intradiegetic pointers to places and buildings, the scanty occurrence of characters that reflect the full range of city dwellers and thus urban society at large, signals that the Shakespearean text is not fully immersed in the texture of the city, that his texts in some sense are alien to or withdraw from certain aspects of urban life. There is on the one hand the tendency in them to be ruralized, while they on the other hand seem to be less concerned with the city as town, and rather more preoccupied about the polis as state and ideology and the individuals' roles in relation to that larger abstract entity. This goes for Julius Caesar and Coriolanus as much as for Measure for Measure. Almost prophetically or programmatically, Shakespeare seems to bring his attitudes to the city to the fore in what is most likely his first play, Two Gentlemen of Verona, as I shall argue shortly.

One wonders whether the dramatist who bought the Old Gatehouse at Blackfriars was merely making a shrewd long-term investment in real estate, or whether he at a deeper level chose the particular location of the gateway, to shut out the monstrous city around him and retreat to the expensive neighbourhood of Blackfriars as a personal variant of the hortus conclusus. Perhaps the answer is both, and in the second instance at least symbolically. Whatever the correct answer may be, and we may never find confirmation, his plays and their many vague urban settings occupy a liminal zone between the pulsating and repulsive city that is so eminently present in the plays of Dekker, Jonson, Marston and Middleton, and the conceptual city and mind-set that the playwright had brought with him from Warwickshire. ${ }^{18}$ That mind-set, be it finessed and reworked throughout his career, is embedded in the attitudes to both architecture and the city in his very first play, Two Gentlemen of Verona, one of four plays set in the Veneto.

In the opening speech of the play, Valentine, sets up a contrast between "the wonders of the world abroad" and "shapeless idleness" of home, that is, an opposition that challenges the preferences of a small-

18 Honan observes that the contemporary views about London differed greatly, being either gloatingly positive and glaringly negative: "Perhaps both views are true- by the end of the sixteenth century London was one of the largest, liveliest and most sophisticated cities in Europe, but it was also overcrowded, squalid, corrupt, crime-ridden and plague-infested" (p. 36). 
town audience, like that of Stratford, where the play may have been penned and first acted. ${ }^{19}$

Cease to persuade, my loving Proteus;

Home-keeping youth have ever homely wits.

Were it not affection chains thy tender days

To the sweet glances of thy honoured love,

I rather would entreat thy company

To see the wonders of the world abroad

Than, living dully sluggardize at home,

Wear out thy youth with shapeless idleness.

But since thou lov'st, love still, and thrive therein,

Even as I would, when I to love begin.

This contrast is inverted at the end of the play when Valentine enters to oppose the calm green world that offers sustenance and the bustling city of wonders:

How use doth breed a habit in a man!

The shadowy desert, unfrequented woods

I better brook than flourishing peopled towns.

Here can I set alone, unseen of any,

And to the nightingale's complaining notes

Tune my distress and record my woes..

(V.iv.1-6)

Unfortunately, or perhaps fortunately, depending on one's preferences, the inhabitants of those "flourishing peopled towns" penetrate into his secluded forest, when "enter Proteus, Silvia and Julia dressed as a page," whom Valentine erroneously believes to be victims of the "uncivil outrages" of his band of outlaws.

They enter to propel the unlikely finale of what very probably was invented as a pastime at Stratford in 1589-90 during Pentecost. Julia's lines at I.i.155-7 would seem to suggest this,

At Pentecost,

When all our pageants of delight were played,

Our youth got me to play the woman's part.

(IV.iv.155-7)

Stanley Wells proposes that "Julia's words form a metatheatrical comment on the action," 21 which I believe is sound because it also draws attention to the self-referentiality so typical of Shakespeare's

\footnotetext{
${ }^{19}$ Stanley Wells, Shakespeare: A Dramatic Life. 1994; London: Methuen, 1997, p. 89.

${ }^{20}$ Two Gentlemen of Verona, ed. Roger Warren, Oxford: Clarendon Press, 2008, p. 71.

${ }^{21}$ Stanley Wells, Shakespeare for All Time. London: MacMillan, 2002, p. 17.
} 
early plays. ${ }^{22}$ A local audience would no doubt have appreciated hearing the city contrasted unfavourably with the wooded landscape around their own home town. It is highly probable that The Two Gentlemen is the first surviving play by Shakespeare, ${ }^{23}$ and that he started out as actor and supplier of material for a local company, like that of a certain "Davy" whose company performed plays at Stratford. ${ }^{24}$

The apprentice play outlines the binary opposition in young Shakespeare's mind-set as a playwright at the point in his life when he was ready to move from the market town to the metropolis to make his fortune as an actor and playwright. He is writing for a prosperous small town and definitely for a non-urban audience. The contrast established in The Two Gentlemen of Verona is between the green world and the alluring prosperous and "peopled" capital, threatening visitors from the country with potential incivility and cozenage. It surely is no coincidence that Shakespeare later in the same speech gives to Valentine architectural metaphors that resurface in 2 Henry IV, when the young man describes the importance of love in his life in terms of edification:

O thou that does inhabit in my breast,

Leave not the mansion so long tenantless

Lest, growing ruinous, the building fall...

$(\text { v.iv. } 7-9)^{25}$

So albeit Shakespeare employs architectural metaphors both for building character and when fashioning his plots, his plays are surprisingly little, or only vaguely, embedded in the bustling life of the city where he worked and lived. Whether early or late in his career as

\footnotetext{
${ }^{22}$ Roger Warren suggests that the play, "with its poetic accomplishment, but arguably primitive dramatic technique, its brevity, and its small cast, might have been planned 'for amateur performance" of the kind proposed by Wells, Shakespeare: A Dramatic Life, p. 89.

23 E.A.J. Honigmann proposes 1587 for a probable date of composition of the play; Shakespeare's Impact on his Contemporaries. Walton-on-Thames: Thomas Nelson \& Sons, 1982, p. 88.

${ }^{24}$ Samuel Schoenbaum first noted the existence of a local theatre company at Stratford who were paid for their services at Pentecost 1583; William Shakespeare: A Documentary Life, Oxford: O.U.P., 1985, p. 89. See also Roger Warren, Two Gentlemen of Verona, pp. 23-24.

25 Clifford Leech comments on the complexity and economy of this speech, observing the "contradiction of 'inhabit' and 'so long tenantless" and the "useful antithesis between 'growing' and 'fall'n' in 1.9 , implying respectively a slow process of decay and a sudden catastrophe.” The Two Gentlemen of Verona, ed. Clifford Leech, Methuen: London and New York, 1986, p. xxiv.
} 
dramatist, the Warwickshire man of the world never quite became part of the "prosperous peopled" city that made it all possible.

Roy ERIKSEN

University of Agder, Kristiansand 